\title{
Study of Investment at the Capital Market in the Firm Sector Performs Well
}

\author{
Dedi Kusmayadi ${ }^{1}$, Irman Firmansyah ${ }^{2}$, Tedi Rustendi ${ }^{3}$ \\ \{*dedikusmayadi@unsil.ac.id\} \\ ${ }^{1,2,3}$ Lecturers at Accounting Department, Faculty of Economics and Business, Siliwangi University
}

\begin{abstract}
This research is a lesson to invest in the capital market in obtaining stock returns in companies listed in LQ45, which are companies that have good liquidity performance. The study was conducted in the period 2013 to 2018 using path analysis. The results found that of the three proposed predictor variables namely size, DER, and ROA, only DER was able to determine stock returns. The effect is positive so the greater the DER ratio, the better the stock returns obtained. Therefore, the amount of debt is not a problem if used as well as possible, because management at this type of company has successfully used funds from external to improve its performance which will ultimately increase returns. Besides, size is found as a variable that can predict ROA, not as a stock return predictor. But the effect is negative so the larger the size of the company the smaller the ROA ratio. This is a unique finding in companies that have high liquidity compared to other types of companies
\end{abstract}

Keyword : Study, Market.

\section{Introduction}

To maintain the company's sustainability, profit is the ultimate goal of the company's operations. Various kinds of business strategies, both internal and external, continue to be developed, especially in an era where business competition is very fierce

Regarding investment in the capital market, investors believe that the level of success of a company in obtaining profits can be assessed from its stock price. So that the goals and expectations of investors in investing their funds in the capital market are to obtain maximum returns with certain risks, and of course will choose companies that have good performance. Accordingly, financial information will be very useful for investors who will invest their capital in the company to assess how much the company's financial performance increases and make predictions about the risks and benefits to be received from the information obtained. Media that can be used to see the company's financial performance is financial statements by analyzing financial ratios.

For investors, stock return is one of the parameters considered in implementing investment decision making. Stock returns are the results obtained from the investment or the level of profits enjoyed by investors for an investment made. A good level of return shows the company's good performance, so that if a company's ability to create profits increases, then the stock price is thought to have the potential to increase. This gives a signal that many investors will be interested because of the potential benefits to be gained in the future. 
Therefore, an important factor in determining the magnitude of stock returns is return on assets. This ratio illustrates the strength of a company's assets in generating profits for a certain period. So that investors also assume that the greater the ROA ratio, the company will have a large stock return as a form of company success in making profits. Anwaar [1] researched companies listed on the London FTSE-100 Index showing a positive influence on ROA on stock returns. While different results were shown by Manaje [2] who conducted a study in the Philippines that ROA has a negative relationship with stock prices even though it is weak.

Some of these studies provide evidence that ROA is an important variable that can be used as material for analysis in investing in the capital market. However, not a few studies have found that ROA is also influenced by many factors, because ROA is a measure of performance, so analysts suspect that one of the suspected factors is company size. Companies that have a larger size have a strong urge to present a high level of profitability. A large and well-established company will be easy to go to the capital market. Because of the ease of dealing with the capital market, it means greater flexibility and a greater level of investor confidence because it has better operational performance. Therefore, the provisional conjecture is that size has a positive effect on ROA. This assumption is reinforced by the results of Kusmayadi, Badruzaman, \& Firmansyah [3] research that conducted research in the banking sector and showed that size affects profitability, as well as Isik, Unal, and Unal [4] research which researched manufacturing sector companies in Turkey showed that size has a positive effect on profitability. So the consistency of the results of research on different objects convinced the writer that size can determine the height of ROA.

Besides, the results of previous studies also indicate that size as a variable is also thought to influence stock returns [5]-[7]. However, this statement contradicts the results of research by Fama and French [8] showing that size is negatively related to stock returns. According to him, large companies were not responded positively by stock returns. This was confirmed also by the results of Dahoei and Saidi's [9] research which researched the Tehran Stock Exchange and Duy \& Phuoc [10] who researched the Ho Chi Minh City Stock Exchange, Also Astakhov et al [11] found that size negatively related to stock returns.

Also, another variable that is often taken into account in analyzing stock returns is leverage. Leverage is an important factor that concerns investors in investment decisions. This ratio is related to the company's ability to repay debt. Companies that can return their debt well will increase investor confidence in the company and can affect the value of the company itself. The study of the relationship between leverage and stock returns has been done by Bhandari [12]. Another study that shows the direction of a definite relationship is the research of Al-Salamat and Mustafa [13] who researched the Amman Stock Exchange that showed a negative influence between capital structure and stock returns, the same result was conducted by Adami et al [14] who researched the London Stock Exchange, and Acheampong et al., [15] who researched in Ghana. However, these studies can be refuted by Bergrren and Bergqvist [16] who researched 50 companies in Sweden. His research successfully showed that financial leverage has a positive influence on stock returns.

Not only that, but leverage is also used to analyze the determination of profitability (return on assets) because the strength of the capital structure through the procurement of debt can increase company liquidity so that it helps the company to improve its financial performance. Studies conducted by Manurung, Suhadak, and Nuzula [17] have proven this with Food and Beverage companies in Indonesia. Another study, Mihaela and Claudia [18] shows that there is a very strong relationship between profitability and debt to equity ratio in the technology company sector, Health Care and Telecommunications 
Currently, we research the Indonesia Stock Exchange in the LQ45 sector, which is a group of companies that have high liquidity. Of course, this sector has a lot of attention from investors because of the interest in this company that has good performance. Therefore, some predictors in previous studies will be tested again in this study to ascertain their impact on stock returns. Not only that, but we also hope that through mediation testing we will find out the role of return on assets in determining stock returns to ensure the importance of ROA for use in capital market analysis.

\section{Methodology}

The data used are companies listed on the Indonesia Stock Exchange and include LQ45 companies, the sampling technique uses purposive sampling with criteria listed and consistently indexed in LQ45 issuers in the observation period of 2013 to 2018.

Table 1. Variable Definitions

\begin{tabular}{|c|c|c|c|}
\hline Variable & Definition & Indicator & Symbol \\
\hline Firm size & Measured by the company's total assets & Total asset & Size \\
\hline Leverage & Measured by comparing total debt to total equity & $\frac{\text { Total Debt }}{\text { Equity }} \times 100 \%$ & DER \\
\hline Profitability & Measured by comparing earning to total asset & earning $x 100 \%$ & ROA \\
\hline $\begin{array}{l}\text { Stock } \\
\text { return }\end{array}$ & $\begin{array}{l}\text { Measured by comparing the current period's stock } \\
\text { price to previous stock price }\end{array}$ & $\begin{array}{c}\text { total asset } \\
\frac{\boldsymbol{P}_{\boldsymbol{t}}-\boldsymbol{P}_{\boldsymbol{t}-\mathbf{1}}}{\boldsymbol{P}_{\boldsymbol{t}-\mathbf{1}}}\end{array}$ & SR \\
\hline
\end{tabular}

The research data were obtained from sources of LQ45 corporate financial statements publications. In this study, the analysis technique used is path analysis. This analysis is felt to be the most suitable to answer the research objectives regarding the determination of stock returns because it will partially know the magnitude of the influence of independent variables namely size, DER, and ROA. Besides, we will also examine ROA as an intermediary variable because ROA is a very important ratio for investors in analyzing stock performance, so many factors influence it. ROA can also affect stock returns because empirical studies have proven it. But in this study, the company sector understudy has its own uniqueness because LQ45 is a company that has the best level of liquidity so that it could be able to refute previous studies

The model built based on theory and empirical studies can be seen in Figure 1.

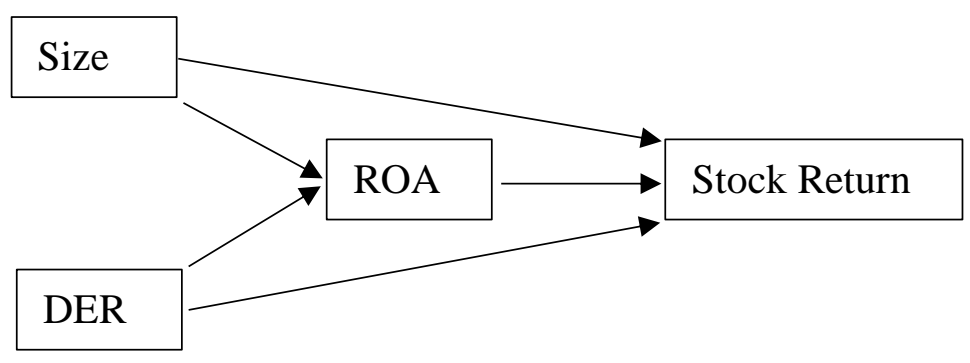

Fig.1. Research Model 
Based on model 1, the basic equations of this study are as follows:

Sub structure 1:

Sub structure 2 :

$$
\mathrm{ROA}=\mathrm{a}+\mathrm{b}_{1} \text { Size }+\mathrm{b}_{2} \text { DER }
$$

$$
\mathrm{SR}=\mathrm{a}+\mathrm{b}_{1} \text { Size }+\mathrm{b}_{2} \mathrm{ROA}+\mathrm{b}_{3} \text { DER }+\mathrm{e}
$$

\section{Result and Discussion}

In testing of substructure 1, the first part of the proposed model is the effect of size and DER on ROA. The results of the analysis can be seen in table 2 .

Table 2. Analysis of Substructure 1

\begin{tabular}{lrrr}
\hline \multicolumn{3}{c}{ Model Summary } \\
\hline $\mathrm{R}$ & & & 0,493 \\
R square & & & 0,243 \\
Var. & Beta & T & sig \\
Size &,- 533 & $-4,717$ &, 000 \\
DER &, 055 &, 484 &, 629 \\
\hline
\end{tabular}

The first model explains the size contribution of the Size and DER variables in predicting ROA of $24.3 \%$, so the remaining $75.7 \%$ is another factor not examined.

Of the two variables, the size of the effect of size on ROA is $53.3 \%$ with a negative coefficient. Then the significance value obtained is 0,000 (this value is below 0.05 ) so it can be concluded that size has a negative effect on ROA. This finding indicates that large companies fail to obtain profits that are proportional to the assets they have, which will increase ROA. Therefore, according to this study, the larger the company size, the lower ROA. Companies that have high liquidity (registered in LQ45) do not show that their liquidity is the result of their main operations, but researchers suspect that liquidity is caused by an injection of funds from external parties. Therefore, there needs to be further studied to find out other factors that are predicted to increase ROA.

Then the magnitude of the effect of DER on ROA is 5.5\%. This effect is very small and compared with a significance value of 0.629 (greater than 0.05 ) so it can be concluded that DER does not affect ROA. Therefore, the DER ratio cannot be used as a predictor by investors in determining the value of ROA. The amount of debt owed by a company that has high liquidity is not a sign that the company is performing well or poorly. This is certainly a unique finding for researchers who then must be developed again in other types of companies in the capital market, especially those that do not have high liquidity as a comparison of research results

Next, we analyze the model of sub-structure 2, with the results in table 4. Sub-structure 2 explains the effect of size, DER, and ROA on stock returns.

Table 3. Analysis of Substructure 2 


\begin{tabular}{llrrr}
\cline { 2 - 4 } & \multicolumn{4}{c}{ Model Summary } \\
\cline { 2 - 5 } & $\mathrm{R}$ & & 0,155 \\
$\mathrm{R}$ square & & & 0,024 \\
Var. & Beta & T & sig \\
Size &,- 113 &,- 811 &, 419 \\
DER &, 222 & 1,720 &, $088^{*}$ \\
ROA &, 030 &, 308 &, 758 \\
\hline
\end{tabular}

Where: *) significant at level $10 \%$

From table 4 it is known that the contribution of variable size, DER, and ROA in predicting ROA is $0.024(2.4 \%)$. This very small contribution indicates that there are still many other variables that are thought to play a large role in building a stock return prediction model.

Meanwhile, the magnitude of the effect of size on stock returns is $11.3 \%$ with a negative coefficient but has a significance value of 0.419 (greater than 0.05 ) which means that size does not affect stock returns. Therefore, a company that has a large fortune does not necessarily indicate that the company has a source of assets from operating profit or the profit from the sale of shares. Financial statement analysts will analyze various sources of the increase in the company's wealth so that accounting has an assessment that the source of wealth can be from the company's profits and can also be from loans. These reasons reinforce the results of this study that statistically there is no significant relationship between company wealth with stock returns obtained.

Companies in the LQ45 sector have a high level of liquidity so stock returns are not determined by the size, but because liquidity is more important. This study adds to the diversity of results with previous studies which results in inconsistencies in results. So as a whole is still following Dimson and Marsh [7] that the size still has not given a definite effect on the capital market.

The next variable is DER which influences $22.2 \%$. The effect is greater than size, and with a significance value of 0.088 (smaller than $0.1 \%$ ) and a positive coefficient, then at a significance level of $10 \%$, DER has a positive effect on stock returns. The positive influence shows that the company certainly requires additional capital when capital from the company's internal parties cannot meet the company's needs so the company needs additional capital from external parties. Also, the high obligation of the company to the creditor can encourage the company to optimize the company's performance so that there is a boost to the company's performance, of course, this can encourage investor interest in investing so that it can directly influence stock prices related to stock returns. These results are consistent with research conducted by Bergrren and Bergqvist [16] which shows that DER has a positive effect on stock returns.

The next variable is return on assets which affects stock returns of only $3 \%$. Besides, the significance value of 0.758 (greater than 0.05 ) concluded that ROA does not affect stock returns. Investors in investing will certainly pay attention to how the company makes a profit. However, it is different from investment analysis in the LQ45 sector because the listing company is a company that has a high level of liquidity not only has a level of profitability. Therefore, the value of ROA in this sector cannot be used to predict stock returns. This finding is important because the LQ45 sector is a company that has the specificity of having the best 
level of liquidity among companies on the Indonesia Stock Exchange. Researchers still find many results that ROA has a positive relationship with stock returns. Therefore there is still confusion among the results of existing research because some indicate a positive relationship and partly a negative relationship between performance and stock returns [1]. Therefore, the findings of this study become one of the reference materials for the development of other studies, especially related to the prediction of stock returns in various sectors in the capital market.

\section{Conclusion}

This study proposes a model used to predict stock returns in companies listed in LQ45. The company here consists of various types of businesses but has excellent liquidity characteristics. However, any sector in investing is not very important if it does not have a good stock return. The analysis found that of the three predictor variables namely size, DER, and ROA, only DER was able to determine stock returns. The effect is positive so the greater the DER ratio, the better the resulting return. Therefore, the amount of debt is not a problem if used as well as possible, because management has succeeded in using funds from external to improve performance.

Because this study uses path analysis, size is found as a predictor of return on assets rather than as a stock return predictor. But the effect is negative so the larger the size of the company the smaller the profitability produced. This is a picture of a company that has high liquidity that has its uniqueness compared to other types of companies.

\section{References}

[1] M. Anwaar, "Impact of Firms' Performance on Stock Returns (Evidence from Listed Companies of FTSE-100 Index London, UK)," Glob. J. Manag. Bus. Res. D Account. Audit., vol. 16, no. 1, 2016.

[2] P. Menaje, "Impact of Selected Financial Variables on Share Prices of Publicly Listed Firms in the Philippines," Am. Int. J. Contemp. Res., vol. 2, no. 9, 2012.

[3] D. Kusmayadi, J. Badruzaman, and I. Firmansyah, "Efficiency and Profitability of Islamic Bank in Indonesia," Adv. Sci. Lett., vol. 23, no. 9, pp. 8807-8812, 2017.

[4] O. Isik, E. A. Unal, and Y. Unal, "The Effect of Firm Size on Profitability: Evidence From Turkish Manufacturing Sector," J. Business, Econ. Financ., vol. 6, no. 4, pp. 301-308, 2017.

[5] R. W. Banz, "The relationship between return and market value of common stocks," J. financ. econ., vol. 9, no. 1, pp. 3-18, 1981.

[6] D. B. Keim, "Size-related anomalies and stock return seasonality: Further empirical evidence," J. financ. econ., vol. 12, no. 1, pp. 13-32, 1983.

[7] E. Dimson and P. Marsh, "Murphy's law and market anomalies," J. Portf. Manag., vol. 25, no. 2, 1999.

[8] E. F. Fama and K. R. French, "Multifactor Explanations of Asset Pricing Anomalies," J. Finance, vol. 51, pp. 55-84, 1996.

[9] S. A. mousavi Dahoei and P. Saídi, "Examining The Relationship Between Company Size and Stock return in Accepted Companies in Tehran Stock Exchange Market," Eur. J. Bus. Manag., vol. 4, no. 9, pp. 57-65, 2012.

[10] N. T. Duy and N. P. H. Phuoc, "The Relationship between Firm Sizes and Stock Returns of Service Sector in Ho Chi Minh City Stock Exchange," Rev. Eur. Stud., vol. 8, no. 4, pp. 210 $219,2016$. 
[11] A. Astakhov, T. Havranek, and J. Novak, "Firm Size and Stock Return: A Meta-Analysis," Prague, 2017.

[12] L. C. Bhandari, "Debt/Equity Ratio and Expected Common Stock Returns: Empirical Evidence," J. Finance, vol. 43, no. 2, pp. 507-28, 1988.

[13] W. A. Al-Salamat and H. H. H. Mustafa, "The Impact of Capital Structure on Stock Return: Empirical Evidence from Amman Stock Exchange," Int. J. Bus. Soc. Sci., vol. 7, no. 9, 2016.

[14] R. Adami, O. Gough, G. Muradoglu, and S. Sivaprasad, "Returns And LeverageProgram," in Oxford Business \& Economics Conference, 2010.

[15] P. Acheampong, E. Agalega, and A. Shibu, "The Effect of Financial Leverage and Market Size on Stock Returns on the Ghana Stock Exchange: Evidence from Selected Stocks in the Manufacturing Sector," Int. J. Financ. Res., vol. 5, no. 1, pp. 125-134, 2014.

[16] S. Berggren and A. Bergqvist, "Capital Structure and Stock Returns-A study of the Swedish large cap companies," University of Gothenburg, 2014.

[17] S. D. Manurung, Suhadak, and N. F. Nuzula, "The Influence of Capital Structure on Profitability and Firm Value," J. Adm. Bisnis, vol. 7, no. 2, pp. 1-8, 2014

[18] H. Mihaela and O. Claudia, "Does Capital Structure Influence Company Profitability?," Stud. Bus. Econ., vol. 12, no. 3, pp. 50-62, 2017. 